Omni-Akuatika, 14 (3): 117-127, 2018
ISSN: 1858-3873 print / 2476-9347 online
Review
journal homepage: http://ojs.omniakuatika.net

\title{
Marine Bioremediation in Indonesia : Die Before Blossom
}

\author{
Agung Dhamar Syakti
}

Center for Maritime Bioscience Studies, Jenderal Soedirman University, Indonesia

Corresponding author: agungsyakti@chemist.com

Received 1 October 2018; Accepted 26 November 2018; Available online 30 November 2018

\begin{abstract}
This critical review highlighted the need to booster an application of the environment biotechnology in order to reduce petroleum hydrocarbons contamination in marine environment. Marine bioremediation can be promisingly applied when the spills occurred. However, absence of policy support from Indonesian government to endorse the private actor's liabilities when complying the rehabilitation action was no significance while academic research was still far from establishment of fundamental knowledge in marine bioremediation. Thus, if so, it very likely that bioremediation disciplines and application might "die before blossom" in a country that often confronted by the maritime risk contamination of petroleum hydrocarbons on their marine and coastal area.
\end{abstract}

Keywords: oil pollution, bioremediation, culturable bacteria, environmental regulation, cost-effective technology

\section{Introduction}

Indonesia is an archipelago state comprising approximately 17,504 islands with a population of over 240 million people who live near the $99,093 \mathrm{~km}$ of coastline. (Geospatial Information Agency of Indonesia 2017). Regarding world oil production, Indonesia used to rank twentieth among world oil producers, with approximately 1.4 percent of the world's daily production, Indonesia's overall crude oil production has decreased from 1.451 million $\mathrm{b} / \mathrm{d}$ to an unofficial 1.06 million b/d (PWC 2010). However, pollutants from oil and gas exploration and exploitation activities are continuously being discharged into Indonesian coastal and marine waters, chronically and accidentally through oil spillage. Table 1 showed the list of oil spill occurring in Indonesian marine water. For instance, in 2015, a broken down on single point mooring in Teluk Penyu Cilacap and a leakage in pipelines release an important quantities of crude oil threatening the mangrove and estuaries ecosystems. Realizing the potential danger to sensitive estuarine and marine habitats, unlike chemical treatments, which produce their own waste by-products, a bio-treatment involving microorganisms, and bioremediation technology, has enjoyed a growth in popularity over the decades, as the 'environmentallyfriendly' option for petrochemical pollutant treatment. Despite their relatively simple application through either the addition of exogenous microorganisms (bioaugmentation) or by stimulating the indigenous microorganisms with the addition of nutrients (biostimulation), the application of petroleum hydrocarbon bioremediation in the marine environment has failed to gain ground as an alternative solution for combating oil spills in Indonesia. This paper reviews the potential application of marine bioremediation to treat hydrocarbon-contaminated marine ecosystems in Indonesia.

In accordance with the Government Regulation (PP) No. 18 year 1999 jo. PP No. 85 year 1999 regarding hazardous waste management, soil or sediment, ecosystems contamination by petroleum hydrocarbons should be addressed rehabilitation by using biological agents to rehabilitate such ecosystems (Goverment Regulation No. 85 1999; Environmental Minister Decree No. 128 2003). Environment Minister Decree No. 128 of the year 2003 allowed bioremediation is a part 
of biotechnology environment that stipulate microbial agents to recover land soil, water and sediments from contamination especially organic compounds. The microbes themselves has been used to remove pollutant substances and other toxic chemicals from domestic waste and industrial output over the last few years. Bioremediation also becomes an intensive field for research and development in academia, Government and industry in several countries including in Indonesia.

Technically, the petroleum hydrocarbons can be bioremediated because microbes can use such chemicals as a source of carbon and energy for reproduction and growth of microorganisms. The term is often referred to as the process of biodegradation. Biodegradation alone can include a lot of the process of with very different output and the consequences. For example, pollutants might be mineralized, converted into a perfect oxidation products such as carbon dioxide, or transformed into other compounds that are more simple and not harmful or toxic, accumulate in the body of the microorganisms, polymerized or attached naturally in soil, sediment, or water (Taylor et al. 2013; Vieira et al. 2018).

\section{Oil Spill History}

The supply and distribution of petroleum hydrocarbons and their refinery products in Indonesia is a very crowded activities, with national oil barges from 1000 tons up to 85,000 tons, and international VLCC (very large crude carrier) tankers carrying from 150,000 to 300,000 tons each. For instance, about 100,000 vessels and 40,000 tankers have transported crude oil and oil products through the Malacca Strait from 1993 to the present day. We can conclude that Indonesian water has a high risk of oil spill disasters, leading to a vulnerable environment for living biota and human health. It is not a myth that Indonesian villagers who live in interaction with the marine environment believe they have witnessed many oil spills occurring in their coastal areas, with different orders of magnitude, but the Indonesian authorities have only been recording oil spills since 1975 (Table 1). From so many spills, we nevertheless cannot obtain a good record concerning the volume spilled and the impact on the environment. Facing such a series of accidents, the Indonesian government has instituted prevention measures through at least 30 rules and regulations related to oil spills and the marine environment. Through multiple government bodies, some regulations have been implemented during the last 40 years. e.g. Presidential Decree No. 109 /2006 concerning the Oil Spill National Contingency Plan. Nevertheless, of all the mitigation measures based on physical and chemical approaches, including the use of mechanical devices such as oil booms and skimmers that are laborintensive, for oil spill response and combating, today bioremediation techniques have begun to be of particular interest.

\section{Petroleum hydrocarbons characterization}

Syakti (2016) characterizes both the petroleum product that is a mixture of organic compounds composed of hydrocarbon compounds (ca. $80-90 \%$ ) and nonhydrocarbons (5-20\%). This hydrocarbons compound can be divided into three categories, namely: (1) hydrocarbon aliphatic (alkanes, alkenes, alkynes; 10 - $40 \%$ ), (2) hydrocarbons alicyclic (cyclo-alkanes, including drimane, hopane and sterane; 30-40\%), (3) aromatic compounds (aromatic compounds or substituted; $10-30 \%)$. During the petroleum industry activities i.e. ranging from drilling, production, transportation, petroleum, refining, and transportation of oil product spills generally occur as well as drops of petroleum and its products.

\section{Biodegradation Processes}

Multiform microorganism that exists naturally in the environment, has a unique metabolic activities and can be used in the handling of the waste or organic materials are dangerous. Biodegradation process of the organic matter into biologically harmful compounds like $\mathrm{CO}_{2}$, methane, water, and the original compounds such as bioremediation. This process is based on the carbon cycle in which the forms of organic and inorganic compounds are recycled through the reaction of oxidation and reduction. Degradation of pollutant compounds always involves the transformation of the structure of the compound so that it changes the molecular integrity of pollutants. So that the process can take optimal environmental conditions required to suit the needs of the growth and reproduction of microorganisms. Optimum conditions are not reached will lead to biochemical degradation microorganisms activity cannot take place with either so toxic compounds become persistent in the environment. In order to achieve the optimum conditions for the degradation of the pollutants then engineering bioremediation applied to manipulate biological systems so that will happen on the desired changes in the 
environment (Sheth et al. 2016). To achieve that goal required an understanding of the principles of the biology of the degradation of toxic compounds, the influence of environmental conditions against related microorganisms and the catalized reactions (Dyer et al. 2003; Chakraborty et al. 2012); In addition to the other sciences are concerned. Furthermore, the reciprocal relationship between microorganisms, energy needs and the environment as well as process control also needs to be considered on the basis of biochemical reactions that take place.

\subsection{Factor affection biodegradation}

Reactions that occur during the process of degradation of pollutants biologically are more complex than when such reactions are based only on chemistry applications. The complexity of the reaction is largely due to the need for the involvement of enzymes specific to entirely catalize existing reactions and enzymes is only produced by microorganismmicroorganism-specific anyway. Therefore, knowledge of basic biological reactions as well as how these reactions are influenced by environmental conditions, is the main requirement in the design of a process of bioremediation. Based on the availability of oxygen, metabolism of microorganisms is distinguished into two kinds, namely aerobic and anaerobic. The microorganisms highly aerobic and aerobic reaction occurred when in an environment that there is enough molecular oxygen acting as electron acceptors. The reaction is known as respiration. The second type, i.e., anaerobic reactions, using organic or inorganic oxides as electron acceptors. Similar to aerobic respiration, anaerobic respiration is taking place, as long as the substrate is oxidized to $\mathrm{CO}_{2}$ through the transfer of $\mathrm{H}^{+}$in quick succession. The end result obtained is a mixture of products more oxidized or reduced more than the substrate first. Depending on the type of microorganims, the final product in the form of acid, alcohols, ketones, and gases (Rontani et al. 2008, 2013). The success of the process of biodegradation much determined by enzyme activity produced by microbes. Thus the microorganisms that could potentially produce the enzyme degrading hydrocarbons need optimized its activities by setting conditions and the addition of the appropriate supplement. In this respect it should be noted that environmental factors include environmental conditions, temperature, oxygen and nutrients are available (Vermelho et al. 2012; Dindar et al. 2015).

\subsubsection{Environment}

Biodegradation processes require the type of land that can support the smooth flow of nutrients, microbial enzymes, and water. The flow has been stopped will lead to formation of anaerobic conditions so that the process of aerobic biodegradation ineffective. The characteristics of the land that is suitable for in situ bioremediation is containing grains of sand or gravel is rough so that the dispersion of oxygen and nutrients can take place properly. Soil moisture is also important to ensure the smooth circulation of nutrients and substrates in the ground (Oh et al. 2001).

\subsubsection{Temperature}

In a process of degradation, the temperature will have an effect on the physical properties and chemical components of oil, speed of degradation by microorganisms, and community composition of microorganisms. The optimal temperature for the degradation of hydrocarbons is $30-40^{\circ} \mathrm{C}$. low temperature On viscosity of oil will increase, resulting in volatility of short-chain alkanes are toxic declined and solubility in water will be increased so that the process of biodegradation will be hampered. Inhibitory effect was also caused by decreased activity of microbial enzymes (Shekhar et al. 2015).

\subsubsection{Oxygen}

The initial step of catabolism of hydrocarbon compounds by bacteria or mold, is the oxidation of substrates with a catalyst enzyme oxidase, thus the availability of oxygen is the success of hydrocarbon degradation condition of oil. The availability of oxygen in the soil depends on (1) the speed of consumption by the microorganism of the soil, soil type (2), and (3) the presence of other substrates reacted with oxygen. The limited oxygen, is one of the limiting factors in the biodegradation of hydrocarbons oil (Colwell 2016). 
Table 1. History of oil spills in Indonesian waters, 1975 - 2009.

\begin{tabular}{|c|c|c|c|}
\hline Year & Location & Accidents & Estimated volume \& oil type \\
\hline 1975 & Malaka Strait & Showa Maru ran aground & 1 million barrels - Diesel oil \\
\hline 1975 & Malaka Strait & $\begin{array}{l}\text { Collision between Isugawa Maru and Silver } \\
\text { Palace }\end{array}$ & n.a. \\
\hline 1979 & Buleleng, Bali & Choya Maru broke up & 300 tons of gasoline \\
\hline 1979 & Lhokseumawe & Golden Win leaked & 1.500 kilo liters of kerosene \\
\hline 1984 & Mahakam delta & Spilled from Total Indonesia & n.a. \\
\hline 1992 & Malaka Strait & $\begin{array}{l}\text { Collision between MT Ocean Blessing and MT } \\
\text { Nagasaki Spirit }\end{array}$ & 5000 barrels of kerosene \\
\hline 1993 & Malaka Strait & Tanker Moersk collision & n.a. \\
\hline 1994 & Cilacap & $\begin{array}{l}\text { Collision between MV Bandar Ayu and fishing } \\
\text { boat }\end{array}$ & n.a. \\
\hline 1996 & Natuna & KM Batamas Sentosa II ran aground & n.a. \\
\hline 1996 & Kepulauan Riau & Tanker MT Kuala Berkaht ran aground & n.a. \\
\hline 1996 & Belawan & MT Pan Oil, ran aground & Crude palm oil \\
\hline 1997 & Banten & TKG Regent III, ran aground & MFO \\
\hline 1997 & Riau archipelago & Orapin Global and Evoikos collide & n.a. \\
\hline 1997 & Riau archipelago & Transfer pipeline leak in Caltex operation field & Crude oil \\
\hline 1997 & Makasar Strait & Mission Vikin ran aground & n.a. \\
\hline 1997 & Makasar Strait & Platform E-20 UNOCAL sank & n.a. \\
\hline 1997 & Madura Strait & SETDCO sank & n.a. \\
\hline 1998 & Tanjung Priok & Kapal Pertamina suplai no 27 struck & n.a. \\
\hline 1998 & Amamapare, Papua & MV Lonian Express, collision & Crude oil \\
\hline 1999 & Batam & Mighty Serent II, ran aground & n.a. \\
\hline 1999 & Tanjung Priok & Pertamina Supply OS. 27, spilled & n.a. \\
\hline 1999 & Siak River Riau & MT Stephanie XVII, collides & gasoline \\
\hline 1999 & Cilacap & crude oil leaked out of MT King Fisher & 1.6 million liters \\
\hline 2000 & Cilacap & $\mathrm{KM} \mathrm{HHC}$ ran aground & 9000 tons of asphaltenic fraction \\
\hline 2000 & Batam & MT Natuna Sea struck & 4000 tons of kerosene \\
\hline 2001 & Tegal-Cirebon & Stedfast ran aground & 1200 tons oily waste \\
\hline 2002 & Bengkalis Riau & TKG Bumindo, hit the ground & MFO \\
\hline 2004 & Wiriagar & TK-OSC 10 , ran aground & Crude oil \\
\hline 2004 & Area TSS & $\begin{array}{l}\text { MV. Kamimasen Hyundai, collision with cargo } \\
\text { vessel }\end{array}$ & n.a. \\
\hline 2004 & Santuriang & MT Pan Sejati ran aground & n.a. \\
\hline 2004 & Teluk Tomini & MT Istana VII, ran aground & n.a. \\
\hline 2004 & Balikpapan & MT Panos 6 leaked & n.a. \\
\hline 2004 & Tomini bay & MT North Star ran aground & n.a. \\
\hline 2004 & Tanjung Balai Karimun & MT Vista Mariner, struck the ground & n.a. \\
\hline 2004 & Pekanbaru & MT Maulana, fire broke out & n.a. \\
\hline 2004 & Cilacap & MT Lucky Lady, leaked & n.a. \\
\hline 2004 & Batu Ampar Batam & KM Swadaya Lestari spilled & n.a. \\
\hline 2004 & Ambon & Tanker MT, PSJT-03 /YB 9043, fire broke out & Diesel oil \\
\hline 2009 & Montara Oil Spill & $\begin{array}{l}\text { Fire broke out on the oil platform Minyak, } \\
\text { Timor sea }\end{array}$ & $4500-34,000$ tons of crude oil \\
\hline 2010 & $\begin{array}{l}\text { Philips stratit (borderlines } \\
\text { Batam vs Singapura) }\end{array}$ & $\begin{array}{l}\text { Collision between KM Bunga Kelana } 3 \text { and KM } \\
\text { Wally }\end{array}$ & 2000 tons - n.a \\
\hline 2015 & $\begin{array}{l}\text { Mallaca strait to eastern } \\
\text { part of Bintan }\end{array}$ & $\begin{array}{l}\text { Tabrakan kapal MT Alyarmouk dengan Kapal } \\
\text { Sinar Kapuas }\end{array}$ & 4500 tons of madura crude oil \\
\hline 2015 & $\begin{array}{l}\text { Perairan Tuban, Jawa } \\
\text { Timur }\end{array}$ & $\begin{array}{l}\text { Leakage of pipelines of Joint Operating Body- } \\
\text { Pertamina Petrichina East Java (JOB-PPEJ) }\end{array}$ & n.a \\
\hline 2015 & Teluk Penyu, Cilacap & Broken on Single Point Mooring of Pertamina & n.a - Crude oil \\
\hline 2016 & $\begin{array}{l}\text { Setianum Susukan } \\
\text { Kecamatan Cirebon }\end{array}$ & Leakage on pipe of Pertamina & n.a \\
\hline 2016 & Kali Donan, Cilacap & Spill from Pertamina & n.a - Solar Industri \\
\hline 2017 & Teluk Bayur Padang & Waste from PT Wira Innomas & 50 ton - minyak kelapa sawit \\
\hline 2017 & $\begin{array}{l}\text { Pasir Gudang Malaka } \\
\text { spread out to Pulau Ubin } \\
\text { Nenas dan Batam }\end{array}$ & $\begin{array}{l}\text { Collision between MT Singapura dengan } \\
\text { Container vessel }\end{array}$ & 300 ton - n.a \\
\hline 2018 & Bintan and Batam water & Unidentified tarball and crude & n.a \\
\hline 2018 & Balik Papan Bay & Broken pipeline of Pertamina & 4000 ton - n.a \\
\hline 2018 & Labuan Bajo & Spilled from MT Roro & n.a \\
\hline 2018 & Gresik water & Unidentified stranded oil & 1.500 barrel $-\mathrm{n} . \mathrm{a}$ \\
\hline 2018 & Pulau Pari & Unidentified stranded oil & n.a \\
\hline 2018 & $\begin{array}{l}\text { Pulau Kubung, Nongsa, } \\
\text { Batam }\end{array}$ & Unidentified stranded oil & n.a \\
\hline
\end{tabular}

n.a. not available 


\subsubsection{Nutrients}

Microorganisms need nutrients as a source of carbon, energy, and balance the metabolism of cells. In the handling of waste oil is usually done the addition of nutrients among other sources of nitrogen and phosphorus and so the process of degradation by the microorganism took place more quickly and its growth increases (Paitan et al. 2003; Drozdova et al. 2013; Mohanram et al. 2016). Ron \& Rosenberg (2002) Stated that theoretically the amount of nitrogen and phosphorus that should be added to convert the one gram of hydrocarbons into the cell material is $150 \mathrm{mg}$ to $30 \mathrm{mg}$ for nitrogen and phosphate. Nitrogen and phosphorus needs to produce maximum growth of hydrocarbons-degrading microorganism can be filled from the addition of these two nutrients last in the form of its alloy with other salts such as ammonium sulfate, ammonium nitrate, ammonium chloride and calcium phosphate. The use of ammonia salts of strong acids will result in a decrease in the $\mathrm{pH}$ of the solution, to avoid such thing then as a source of nitrogen urea can be used. Previous works recommend the addition of the $\mathrm{C}: \mathrm{N}: \mathrm{P}$ of $120: 10: 1$ in the form of inorganic fertilizers to enhance biodegradation of hydrocarbons, especially on the ground. Morgan and Watkinson (1989) stated that the C: N ratio of the optimum is between 9:1 and 200:1. In the results of the study by Margesin and Schinner (2001) about the degradation of diesel oil, the $\mathrm{C}: \mathrm{N}$ ratio is best to $60: 1$.

\subsubsection{Enzymes activities}

In the absence of an enzyme reaction mengkcatalizing the degradation, the time required to reach equilibrium for long. Enzymes speed up the process by means of lowering the activation energy, namely the energy required to start a reaction. Ability to lower the activation energy reduction-oxidation reactions are very specific. Some kind of enzyme requires cofactors, i.e. compound catalytic active complex with the ability that is formed from the combination of the non-protein compounds with proteins pepsinogen. Cofactors can be either a metal ion such as $\mathrm{Fe} 2+$ or $\mathrm{Fe} 3+, \mathrm{Co} 2+$, $\mathrm{Cu} 2$ ,$+ \mathrm{Mg} 2+, \mathrm{Mn} 2+, \mathrm{Ca} 2+$, and $\mathrm{Zn} 2+$; and organic materials such as Coenzyme A (Cookson area, 1995). Enzyme production is triggered by the presence of a substrate which serves as a source of energy. The substrate can be either pollutant compounds or not pollutants. So that microorganisms could obtain energy from the substrate, then the material should go into the cell membrane and passes through a series of electron transport during respiration

\section{Bioremediation}

The selection of a method of bioremediation that match the environmental conditions expected to be able to increase the speed of biodegradation. Two methods are wont to do to is to stimulate microbial populations of indogen (biostimulation), and by adding exogenous microorganisms (bioaugmentation). Bioaugmentation selected when the contaminant degradation takes a long time, when a contaminated environment difficult modified in order to achieve optimum condition for the growth of microorganisms or when high concentrations of contaminant shifted the growth of microorganisms indigenous (Balasubramanian et al. 2010; Roy et al. 2018). In addition, bioaugmentation also made to lose the diversity of hydrocarbon degradation pathway mainly to accelerate the process of degradation of the hydrocarbons polyaromatic (Ron \& Rosenberg 2002). The successful application of bioaugmentation is measured from an increasing number of microorganisms that play a role in the process of degradation as well as the durability of exogenous microorganisms in polluted environments. In fact not all microorganisms are added to able to survive in new environments and contribute significantly in the process of degradation of components pollutants. To acquire a strain of microorganisms or microbial consortium is right for bioaugmentation applications, there is a choice of three methods that can be done, IE: selective use of enriched products commercial microorganisms or genetically engineered (Lui et al. 2005; Sheth et al. 2016). Selective enriched is essentially a method to increase the population of certain microorganisms of a given inoculum (the source of the microorganism). These sources can be a sludge, soil or groundwater from waste treatment location or other contaminated environment. For the purposes of handling hydrocarbon waste, animal waste can also be utilized as a source of microorganisms alternative because the waste contains microorganisms anaerobic and aerobic which play a role in the degradation of organic materials.

\section{Microorganism}

According to Rosenberg and Ron (1998), the characteristics of the microorganism that can be utilized in the degradation of 
hydrocarbons are: (1) can produce the enzyme membrane bound enzyme that is specific and oxygenase (2) have a specific mechanism to optimize contact between microorganisms with hydrocarbons. These mechanisms can occur through the interaction between the hydrophobic cell surface microorganisms with hydrocarbons. Thus the properties of the hydrophilic cell surface is the key to successful shapping microorganisms in hydrocarbon granules.

One group of microorganisms that are important in the process of degradation is bacteria. Bacteria are unicellular organisms that reproduce by binary fission. The shape of the cell, bacteria can be distinguished into three namely: coccus (spherical), rods, and spirals. The outermost structure of bacteria there are protected by a capsule or slime. Bacterial cell size ranges between $0.3-3.0 \mu \mathrm{m}$. Bacterial stem has a size of $0.5-1.0 \mu \mathrm{m}$ in width and length While coccus bacteria have a diameter of $0.5-1.0 \mu \mathrm{m}$. The capsule is comprised between $100 \AA-300 \AA$ and composed of polysaccharides or polypeptide which serves to protect the bacteria from predatorisme by protozoa. The presence of capsules or slime that can also be utilized in the process of handling liquid waste. Mucus that formed from natural polymers that will make the bacteria stick to each other forming the flok so that bacteria can easily be separated from the biological reactor effluents. The production of the polymer is a function of nutrient and growth stages of organisms (Pacwa-Płociniczak et al. 2016; Parthipan et al. 2018).

\section{Microbial adaptation in contaminated environment}

The content of hydrocarbons in the environment contaminated oil was relatively higher than the normal environment. In the circumstances, the microorganisms can survive is that it has the ability to change the biochemical process of the initial response and adaptive to changes in the surrounding environment. Miguez et al. (1993) describes three ways that is microorganisms to adapt to their environment, namely:

- $\quad$ specific enzyme Induces certain level of degradation to the overall population of microorganisms is increasing.

- the growth of microorganisms that are capable of taking the subpopulations and metabolize the substrate.

- $\quad$ selection of the mutant was able to produce specific enzymes or certain metabolic activity.
It is well known that the plasmids play an important role in microbial adaptation. Plasmids with genes represent a high mobility that can be transferred through a process of conjugation and translation so that why, phenotipical properties will be expressed. The phenotypic properties, among others, in the form of oxidizing enzymes producing ability of hydrocarbons (Ivshina et al. 2016). Various genes coding, enzymes involved in metabolic pathways naftalene, salicylate, octane, xilene, and toluene; have been known to subsist in Pseudomonas spp (Whyte et al. 1997). Studies conducted by Thiel et al. (2005) suggests that the enzyme degradation of coding-gene chlorocathecol was located in plasmids and plasmids to the transmission in other microorganisms will allow microorganisms to recipients as well degrade the chlorinated compounds.

\section{Microbial interaction}

Other phenomena also need to get attention in optimizing the activities of microorganisms in bioremediation is the interaction between some strains of microorganisms in the environment. One of its form is co-metabolisme. Other important metabolic concept in bioremediation is cometabolisme. Co-metabolisme is the process of transformation of compounds indirectly so that no energy is generated. Even so, this process could take place because the enzyme produced microorganisms to degrade specific substrate turns can also be beneficial to the process of degradation of other compounds that have nothing to do with the process of energy production, carbon assimilation as well as other processes related to the growth of the microorganism. This process can only take place when it is available for other substrate which acts as a source of carbon for metabolism of microorganisms (Hidayati et al. 2011; Cai et al. 2014).

Various compounds of toxic pollutants including hydrocarbons and aromatic compounds polynucleous, aromatic and aliphatic hydrocarbons, halogenated, as well as pesticides can be degraded in co-metabolisme. In co-metabolism, the compounds will undergo partial transformation, when the reaction stops until there alone, these compounds could be transformed into more toxic secondary substrates. Therefore, there needs to be other microorganisms that are able to use a secondary substrate last as a source of major carbon so that the process of transformation of pollutants can be perfectly (Robles-González et al. 2008). 
Difficulties that may arise in cometabolism is the competition between the substrate carbon sources by pollutants in the starting side of the active enzyme degradation. The type of inhibition is referred to as competitive inhibition. One of the ways that can be done to overcome it is by lowering the overall level of the substrate competition, i.e. by pressing source concentration.

\section{Marine Bioremediation Research in Indonesia}

In fact, bioremediation research in Indonesia started in the 1970s, but those applications were limited to the soil environment. Many works related to waste management in oil and gas activities. To date, there is no record of full-scale application of oil spill marine bioremediation in the marine and coastal environment in Indonesia (Darmayati 2009, 2010). As far as we are concerned, bioremediation can be implemented as in situ and ex situ methods. Those which may be involved are bioaugmentation, biostimulation, and natural monitored bioattenuation (Mrozik \& Piotrowska-Seget 2010).

\section{Bioaugmentation}

On the laboratory scale, the development of bioremediation studies in the marine environment has focused on the enumeration, isolation and identification of hydrocarbondegraders. The first study in that vein was conducted by Thayib (1978) and showed the distribution of hydrocarbonoclastic bacteria in Jakarta Bay. A study on the natural biodegradation of oil and the development of a microbial consortium to eliminate the oil pollution has been conducted at the University of Hasanudin (Noor, 1999). A similar study has been conducted by Darmayati (2003) exhibited in the Makassar Strait and Java Sea. Another study was conducted to screen the culturable hydrocarbon ( $\mathrm{HC}$ )-degrading microorganisms isolated from petroleum-polluted soils and cyanobacterial mats from Indonesia, resulted in the collection of 33 distinct species, in aerobic system. Eight bacteria, 21 fungi and four yeasts were specifically identified (Chaillan et al. 2004). Recently, Syakti et al (2008) demonstrated the bioremediation potential of hydrocarbonoclastic bacteria isolated from a mangrove contaminated by petroleum hydrocarbons on the Cilacap coast, Indonesia. Table 2 shows some studies conducted by several researchers from different Indonesian Institutions (Table 2).

One important milestone in bioremediation research was emphasized by the collaboration between the Indonesian Institute of Sciences and the National Institute of Technology and Evaluation (NITE, Japan) in 2005, which improved the Indonesian scientists' ability to conduct research related to isolation and identification of oil degrading bacteria in Indonesia using a biomolecular approach. For instance, Darmayati (2010) isolated 131 different hydrocarbonoclastic bacterial strains from Jakarta Bay and Seribu Island. Some isolates (11 strains) were indicated as new strains. The common genera found were Alcanivorax, Marinobacter, Bacillus and Achromobacter. Further study in Jakarta ports showed that hydrocarbonoclastic bacteria from those sites consisted of 37 strains of fluoranthene-degrading bacteria, 30 strains of crude oil degrading bacteria, 25 strains of fluorene-degrading bacteria, nine strains of phenanthrene-degrading bacteria, nine strains of naphthalene-degrading bacteria, eight strains of dibenzothiophene-degrading bacteria and seven strains of pyrene-degrading bacteria (Darmayati 2010; Alfiansah et al. 2014). Moreover, within the same project, Sudiana et al., (2009) conducted research that included morphology, physiology, chemotaxonomy and phylogeny of several groups, namely alphaproteobacteria, gamma-proteobacteria, Flavobacteria, and Actinobacteria with a potential genus novum which belongs to Rhodobacteriales. One of them was a new species within Rhodovulum. Based on the taxonomic data obtained in this study, a novel species, Salipiger pariensis sp.nov, is proposed; RI-P1_LIPIMC is the type strain for Salipiger pariensis. Another study conducted by Teramoto and co-authors mentioned Erythrobacter/Altererythrobacter-related bacteria as the predominant isolates from the actual crude-oil-polluted Indonesian sea site (Teramoto et al. 2010). Some studies were also focused on the sub-cellular level, including functional gene screening of bacteria responsible for hydrocarbon degradation. For instance, Yopi (2009) found the sequences of mono-oxygenase genes from eight isolate strains that showed the diversity of alkene mono-oxygenase sequences from bacteria with different taxa. 
Table 2. Isolated oil-degrading bacteria from Indonesian marine ecosystems

\begin{tabular}{|c|c|c|}
\hline Isolated microorganisms & Institution & Sources \\
\hline $\begin{array}{l}\text { Acinetobacter sp., Arthrobacter sp, Micrococcu } \\
\text { s sp, Bacillus sp }\end{array}$ & University of Riau & Feliatra (1999) \\
\hline $\begin{array}{l}\text { Acinetobacter sp., Brevibacterium sp., Bacillus } \\
\text { sp. }\end{array}$ & University of Hasanudin & (Noor, 1999) \\
\hline Pseudomonas cepacia, P. gladioli & $\begin{array}{l}\text { Research Center for Oceanography - } \\
\text { LIPI and Bogor Agricultural University }\end{array}$ & Susilawati (2000) \\
\hline 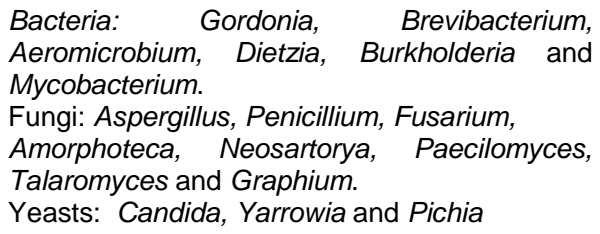 & $\begin{array}{l}\text { Muséum National d'Histoire Naturelle, } \\
\text { Paris }\end{array}$ & Chaillan et al (2004) \\
\hline $\begin{array}{lrr}\text { Alcanivorax, } & \text { Marinobacter, } & \text { Bacillus, } \\
\text { Achromobacter, } & \text { Alcaligenes, } & \text { Bacillus, } \\
\text { Pseudomonas, Bordetella, Sphingomonas, etc }\end{array}$ & $\begin{array}{l}\text { Research Center for Oceanography - } \\
\text { LIPI }\end{array}$ & Darmayati et al., (2008) \\
\hline $\begin{array}{l}\text { Bacillus aquimaris, Bacillus megaterium, } \\
\text { Bacillus pumilus, Flexibacteraceae bacterium, } \\
\text { Halobacilus trueperi, and Rhodobacteraceae } \\
\text { bacterium. }\end{array}$ & Jenderal Soedirman University & Syakti et al (2008) \\
\hline $\begin{array}{lcc}\text { Aeromonas } & \text { hydrophila, } & \text { Enterobacter } \\
\text { agglomerans, } & \text { Shewanella } & \text { putrefaciens, } \\
\text { Acinetobacter } & \text { haemolyticus } & \text { and Vibrio } \\
\text { alginolyticus } & & \end{array}$ & $\begin{array}{l}\text { Research Center for Oceanography - } \\
\text { LIPI }\end{array}$ & Darmayati (2009) \\
\hline
\end{tabular}

\section{Biostimulation}

Biostimulation using urea, modified customblen and oleophilic as fertilizer has been tested on oil-polluted sea water columns by mesocosm approaches in field experiments (Ruyitno, 1997). Bioaugmentation has also been studied using single culture and consortium local bacteria with the same approaches. Biostimulation studies were performed from a laboratory scale and microcosm scale to field experiments (sand column). These focused on bioremediation in a sandy beach environment, unlike the previous experiment which concentrated on the water column. The present studies showed that "Osmocote" was the best slow-release fertilizer compared to other studies. The study also revealed that the microbial community succession during the bioremediation processes, the proper amount of fertilizer and the period of fertilizer application should be suitable, and also the impact on microalgae growth (Darmayati 2010; Alfiansah et al. 2014) . Another approach with a view to biostimulation is related to biosurfactant-producing bacteria. Some studies can be cited here, including the work of Susilawati (2009) on the biodiversities of surfactant bacteria from Jakarta Bay and Pari Island. Recently, Hidayati et al (2011) conducted a study on the removal of polyaromatic hydrocarbons by biosurfactantproducing bacteria isolated from a chronically contaminated mangrove. Overall, in the marine environment some aspects supporting a comprehensive study of biodegradation processes that involve various factors such as pollutants, microorganisms, energy sources, physical and chemical conditions, toxicity, competition, and metabolite accumulation are welcome in Indonesia.

The development of bioremediation technology in Indonesia is still promising to be applied in certain cases of oil spills in the marine environment i.e. sandy beaches and mangrove forests. The regulatory factor is not becoming the limiting factor for the full-scale application of bioremediation with regard to Presidential Decree No. 109/2006 concerning the Oil Spill National Contingency Plan. However, it is not easy to produce a manual or guidelines on conducting bioremediation in the marine environment, and many steps still remain to be taken. Several aspects concerning this study, such as the diversity of characteristics of the polluted sites, oil characteristics, oceanographic conditions and engineering must be studied comprehensively. In addition, some trial-and-error tests need to be passed to confirm the result, to identify and 
overcome the limitations, and there is a real need to ensure that the discoveries made in the laboratory can be successfully applied in the field. At present, in Indonesia there are two technical guidelines from two government bodies, the ministries of the environment and marine affairs of the Republic of Indonesia (under review), which mention bioremediation as an option for oil spill response and rehabilitation action plans.

Much research has been conducted by Indonesian universities and research agencies such as the Indonesian Institute of Sciences, but universities do not offer qualifications in areas of bioremediation engineering expertise such as microbiology, engineering, geology, hydrogeology, soil science and project management. One of the ways to reduce this gap could be through support by venture capital investment in bioremediation technology; indeed, the private sector is facing an emerging opportunity to play a role by providing bioremediation application technical support, since a successful bioremediation program requires a multidisciplinary approach that can be acquired only through experience and onthe-job training. Meanwhile, from a liability standpoint, the private sector does not take a greater risk for the accomplishment of the predetermined goal of bioremediation programs. As a consequence, commercial activity in $R$ \& $D$ has lagged far behind other industrial sectors.

\section{Concluding Remarks and Future Trends}

To conclude, we started with a fundamental question, would collaboration across government, academic and private sector will promote the development of marine bioremediation as a tools for oil spill response.eliminate the petroleum impact. Bioremediation techniques and technologies can be chosen as the most suitable method for oil spills or any accidental release of petroleum hydrocarbons in the marine environment. For Indonesian scientists, challenges and opportunities are available to the improve deployment of this technology to mitigate oil spillages. Many steps need to be taken to develop bioremediation technology, including research activities in a variety of topics, such as microbial ecology studies for specific activities (i.e., photosynthesis, respiration, degradation), experiments to investigate the potential stability and capability of 'bio-sorb' as inoculants, the use of slow-release fertilizer combined with chemical/biological surfactants, and so on. Collaborative research intra- and inter- disciplines/institutes/countries will be favorable for the use of biological agents on oil pollution control. Nevertheless, one other important aspect that makes the development of bioremediation be restricted is because of the absence of any obligation of the company doing the bioremediation when oil spill incident occurs in marine environment. Thus, if so, it very likely that bioremediation disciplines and application might "die before blossom" in a country that often confronted by the maritime risk contamination of petroleum hydrocarbons on their marine and coastal area.

\section{Acknowledgement}

This work was supported by the Competitive Grant from Ministry of Research, Technology and Higher Education of the Republic of Indonesia (2029/UN23.14/PN/2018).

\section{References}

Alfiansah, Y.R., Adindasari, M., Argarini, M. \& Darmayati, Y. (2014). Isolation and Distribution of Crude Oil and Polycyclic Aromatic Hydrocarbon-Degrading Bacteria From. 39, 79-85.

Balasubramanian, V., Natarajan, K., Hemambika, B., Ramesh, N., Sumathi, C.S., Kottaimuthu, R. \& Rajesh Kannan, V. (2010). High-density polyethylene (HDPE)-degrading potential bacteria from marine ecosystem of Gulf of Mannar, India. Letters in Applied Microbiology, http://dx.doi.org/10.1111/j.1472765X.2010.02883.x.

Cai, Q., Zhang, B., Chen, B., Zhu, Z., Lin, W. \& Cao, T. (2014). Screening of biosurfactant producers from petroleum hydrocarbon contaminated sources in cold marine environments. Marine Pollution Bulletin, 86, 402-410, http://dx.doi.org/ 10.1016/j.marpolbul.2014.06.039.

Chakraborty, R., Wu, C.H. \& Hazen, T.C. (2012). Systems biology approach to bioremediation. Current Opinion in Biotechnology, 23, 483-490, http://dx.doi.org/10.1016/j.copbio.2012.01. 015.

Colwell, R.R. (2016). The Gulf of Mexico research initiative: It takes a village. Deep Sea Research Part II: Topical Studies in Oceanography, 129, 2-3.

Darmayati, Y. (2010). Bioremediation of Crude 
Oil Contaminated Sediment Using Slow Release Fertilizer: Hydrocarbonoclastic Bacteria Population Dynamics. 2, 462476.

Darmayati, Y. (2009). Development of oil bioremediation research on marine environment in indonesia. Development, 12, 105-110.

Dindar, E., Topaç Şağban, F.O. \& Başkaya, H.S. (2015). Variations of soil enzyme activities in petroleum-hydrocarbon contaminated soil. International Biodeterioration \& Biodegradation, 105, 268-275,

http://dx.doi.org/10.1016/j.ibiod.2015.09.0 11.

Drozdova, S., Ritter, W., Lendl, B. \& Rosenberg, E. (2013). Challenges in the determination of petroleum hydrocarbons in water by gas chromatography (hydrocarbon index). Fuel, 113, 527-536, http://dx.doi.org/10.1016/j.fuel.2013.03.05 8.

Dyer, M., Heiningen, E. Van \& Gerritse, J. (2003). A field trial for in-situ bioremediation of 1, 2-DCA. 70, 315-320, http://dx.doi.org/10.1016/S00137952(03)00099-1.

Environmental Minister Decree No. 128. (2003). Tata Cara dan Persyaratan Teknis Pengolahan Limbah Mlnyak Bumi dan Tanah Terkontaminasi oleh Minyak Bumi Secara Biologis. 0.

Geospatial Information Agency of Indonesia. (2017). Identification of islands and standardization of their names submitted by Indonesia. 11th United Nations Conference on the Standarization of Geographical Names.

Goverment Regulation No. $85 . \quad$ (1999). Peraturan Pemerintah Republik Indonesia 85 Tahun 1999 Tentang Pengelolaan Limbah Bahan Berbahaya Dan Beracun. 1-233, http://jdih.menlh.go.id/pdf/ind/INDPUU-3-1999-PP No. 85 Tahun 1999.pdf.

Hidayati, N.V., Hilmi, E., Haris, A., Effendi, H., Guiliano, M., Doumenq, P. \& Syakti, A.D. (2011). Fluorene removal by biosurfactants producing Bacillus megaterium. Waste and Biomass Valorization, 2 , http://dx.doi.org/10.1007/s12649-0119085-3.

Ivshina, I., Kostina, L., Krivoruchko, A., Kuyukina, M., Peshkur, T., Anderson, P. \&
Cunningham, C. (2016). Removal of polycyclic aromatic hydrocarbons in soil spiked with model mixtures of petroleum hydrocarbons and heterocycles using biosurfactants from Rhodococcus ruber IEGM 231. Journal of Hazardous Materials, 312, 8-17, http://dx.doi.org/10.1016/j.jhazmat.2016.0 3.007.

Lui, E., Zhao, H. \& Obbard, J.P. (2005). Recent advances in the bioremediation of persistent organic pollutants via biomolecular engineering. 37, 487-496, http://dx.doi.org/10.1016/j.enzmictec.2004. 07.024.

Miguez, C.B., Greer, C.W. \& Ingram, J.M. (1993). Purification and Properties of Chlorocatechol 1,2- Dioxygenase from Alcaligenes denitrificans BRI 6011. Can J Microbiol, 39, 1-5, http://dx.doi.org/10.1139/m93-001.

Mohanram, R., Jagtap, C. \& Kumar, P. (2016). Isolation, screening, and characterization of surface-active agent-producing, oildegrading marine bacteria of Mumbai Harbor. Marine Pollution Bulletin, 105, 131-138,

http://dx.doi.org/10.1016/J.MARPOLBUL.2 016.02.040.

Mrozik, A. \& Piotrowska-Seget, Z. (2010). Bioaugmentation as a strategy for cleaning up of soils contaminated with aromatic compounds. Microbiological Research, 165, 363-375, http://dx.doi.org/10.1016/j.micres.2009.08. 001.

Oh, Y., Sim, D. \& Kim, S. (2001). E $€$ ects of Nutrients on Crude Oil Biodegradation in the Upper Intertidal Zone. 42, 1367-1372.

Pacwa-Płociniczak, M., Płociniczak, T., Iwan, J., Żarska, M., Chorążewski, M., Dzida, M. \& Piotrowska-Seget, Z. (2016). Isolation of hydrocarbon-degrading and biosurfactantproducing bacteria and assessment their plant growth-promoting traits. Journal of Environmental Management, 168, 175184 , http://dx.doi.org/10.1016/j.jenvman.2015.1 1.058.

Paitan, Y., Biran, D., Biran, I., Shechter, N., Babai, R., Rishpon, J. \& Ron, E.Z. (2003). On-line and in situ biosensors for monitoring environmental pollution. 22, 27-33, http://dx.doi.org/10.1016/j.biotechadv.200 3.08.014. 
Parthipan, P., Elumalai, P., Ting, Y.P., Rahman, P.K.S.M. \& Rajasekar, A. (2018). Characterization of hydrocarbon degrading bacteria isolated from Indian crude oil reservoir and their influence on biocorrosion of carbon steel API $5 \mathrm{LX}$. International Biodeterioration \& Biodegradation, 129, 67-80, http://dx.doi.org/10.1016/j.ibiod.2018.01.0 06.

PWC. (2010). Oil and Gas in Indonesia. Taxation.

Robles-González, I. V., Fava, F. \& PoggiVaraldo, H.M. (2008). A review on slurry bioreactors for bioremediation of soils and sediments. Microbial Cell Factories, 7, 116, http://dx.doi.org/10.1186/1475-2859-75.

Ron, E.Z. \& Rosenberg, E. (2002). Biosurfactants and oil bioremediation. Current Opinion in Biotechnology, 13, 249-252, http://dx.doi.org/10.1016/S09581669(02)00316-6.

Rontani, J.-F., Bonin, P., Vaultier, F., Guasco, S. \& Volkman, J.K. (2013). Anaerobic bacterial degradation of pristenes and phytenes in marine sediments does not lead to pristane and phytane during early diagenesis. Organic Geochemistry, 58, 43-55,

http://dx.doi.org/10.1016/j.orggeochem.20 13.02.001.

Rontani, J.-F., Nassiry, M., Guasco, S., Mouzdahir, A. \& Bonin, P. (2008). Aerobic metabolism of vitamin $E$ by marine bacteria: Interaction with free radical oxidation (autoxidation) processes. Organic Geochemistry, 39, 676-688, http://dx.doi.org/10.1016/j.orggeochem.20 08.02.018.

Roy, A., Dutta, A., Pal, S., Gupta, A., Sarkar, J., Chatterjee, A., Saha, A., Sarkar, P., Sar, P. \& Kazy, S.K. (2018). Biostimulation and bioaugmentation of native microbial community accelerated bioremediation of oil refinery sludge. Bioresource Technology, 253, 22-32, http://dx.doi.org/10.1016/j.biortech.2018.0 1.004.

Shekhar, S., Sundaramanickam, A. \& Balasubramanian, T. (2015). Biosurfactant producing microbes and their potential applications: A review. Critical Reviews in Environmental Science and Technology, 45, 1522-1554, http://dx.doi.org/ 10.1080/10643389.2014.955631.
Sheth, R.U., Cabral, V., Chen, S.P. \& Wang, H.H. (2016). Manipulating Bacterial Communities by in situ Microbiome Engineering. Trends in Genetics, 32, 189200, http://dx.doi.org/10.1016/j.tig.2016.01.005.

Syakti, A.D. (2016). Molecular Diagnostic Ratios To Assess the Apportionment of Petroleum Hydrocarbons Contaminantion in Marine Sediment. Molekul, 11, 208, http://dx.doi.org/10.20884/1.jm.2016.11.2. 236.

Taylor, P., Journal, B., Syakti, A.D., Hidayati, V., Sahri, A. \& Doumenq, P. (2013). The Bioremediation Potential of Hydrocarbonoclastic Bacteria Isolated From a Mangrove Contaminated by Petroleum Hydrocarbons on the Cilacap Coast , Indonesia. 37-41, http://dx.doi.org/10.1080/10889868.2012.7 31446.

Thiel, M., Kaschabek, S.R., Gröning, J., Mau, M. \& Schlömann, M. (2005). Two unusual chlorocatechol catabolic gene clusters in Sphingomonas sp. TFD44. Archives of Microbiology, 183, 80-94, http://dx.doi.org/10.1007/s00203-0040748-3.

Vermelho, A.B., Supuran, C.T. \& Guisan, J.M. (2012). Microbial enzyme: Applications in industry and in bioremediation. Enzyme Research, http://dx.doi.org/10.1155/2012/980681.

Vieira, G.A.L., Magrini, M.J., Bonugli-Santos, R.C., Rodrigues, M.V.N. \& Sette, L.D. (2018). Polycyclic aromatic hydrocarbons degradation by marine-derived basidiomycetes: optimization of the degradation process. Brazilian Journal of Microbiology,

$1-8$, http://dx.doi.org/10.1016/j.bjm.2018.04.00 7.

Whyte, L.G., Bourbonniére, L. \& Greer, C.W. (1997). Biodegradation of petroleum hydrocarbons by psychrotrophic Pseudomonas strains possessing both alkane ( alk ) and naphthalene Biodegradation of Petroleum Hydrocarbons by Psychrotrophic Pseudomonas Strains Possessing Both Alkane ( alk ) and Naphthalene (n.). 